\title{
CUSTOMERS SATISFACTIONS ON INTERNET BANKING - A STUDY WITH RESPECT TO FOREIGN BANKS AT CHENNAI CITY
}

\section{G. Chandana Deepa}

Ph.D. Research Scholar (Part Time), P.G \& Research Department of Commerce, Government Arts \& Science College, (Previously Bharathidasan University Constituent College), (Affiliated to Bharathidasan University, Trichy, Tamilnadu, India

\section{Dr. M. Raja}

Assistant Professor, P.G \& Research Department of Commerce, Government Arts \& Science College, (Previously Bharathidasan University Constituent College), (Affiliated to Bharathidasan University, Trichy, Tamilnadu, India

\begin{abstract}
Internet banking is facilitates to customers made their financial transactions through website using Internet. Entry of foreign banks in India gives cut throat competition among private and public sector banks in offering new innovative services to their customers using technology. The foreign banks takes all most care to satisfy their customers in various aspects like prompts responses, banking securities, Reliability \& Confidence, Efficiency of website and website design. The present study on customer's satisfaction on internet banking services offered by foreign banks in Chennai city covers only five foreign banks in Chennai city namely Standard Chartered Bank Ltd, Citibank, HSBC Bank, Deutsche Bank and DSB Bank. It is very clear from the present study that sample that sample foreign banks in Chennai city offer various innovative and modern features through internet banking using the latest technology to satisfy their customers.
\end{abstract}

Key words: Foreign Banks, Internet Banking Services, Customer Satisfactions, Customer Services

Cite this Article: G. Chandana Deepa and M. Raja, Customers Satisfactions on Internet Banking - A Study with Respect to Foreign Banks at Chennai City, International Journal of Management, 11(12), 2020, pp 851-857.

http://iaeme.com/Home/issue/IJM?Volume=11\&Issue=12

\section{INTRODUCTION}

Information Technology act 2000 of India provides the great opportunity to the Indian banking industry in the area of technological adoption, innovation and introduction to new 
financial product and services and real time service to their customers. This act recognized the electronic transactions, electronical data interchange, electronical fund transfer and other means of E-Commerce. 'Working Group on Internet Banking' set by Reserve Bank of India gave the major recommendations to internet banking, E.Banking. The committee frame major legal frame works for regulations, supervisions, security and technological aspects. This committee recommends the various regulations regarding different aspects of Internet banking consolidated payment systems. This recommendation facilitate to Electronic Funds Transfer (EFT), Foreign exchange clearance and real time gross settlement (RTGS). India is a largest user of internet next to China especially in the area of banking and financial sector. In India there is a wider scope for banking and financial institution to expand their Internet banking customer base.

\subsection{Review of Literature}

Cronin, J. and Taylor, S. (1992) performance-based measure must improve to measure the service quality and service quality is an antecedent of consumer satisfaction. Gerrard, P. \& Cunningham, J.B. (2003), In Singapore adopters of Internet banking perceives the service to be more convenient, less complex and more compatible to customers. Raed Awamleh etal.(2005) United Arab Emirates must use the real added value tools to improve the customers satisfactions. Laforet, S \& Lo, X. (2005) Ghana should create more awareness through personal interaction with customers; develop quality initiatives in order to build customer's confidence. Raja.M and Dr.Clement Sudhahar.J (2009) Indian stock market absorbed the stock split announcement information and prices of shares increased considerably after the announcement. D Baskar, S. \& Ramesh.M (2010), customer service quality, information system quality and banking product quality are significantly influence the customers satisfactions. Konstantinos Terzidis, Eva Papadopoulos etal (2013) trust and alternative channel are significant for forecasting the customer e-loyalty but overall customers are not satisfied with internet banking services. Dr.M.Raja and Dr.R.Venkatamuni Reddy etal (2018) developed the model portfolio using sharp index model in CNF Nifty bank index the high risk obtained by Canara bank and low risk was obtained by and Indian bank respectively. Vigneshwari and S.Rajagopalan (2018 customers are satisfied with online banking in terms of convenient and flexibility in using the online banking. Dr.Kiran.G and Dr.M.Raja, etal (2020) bank prompt responses, banks website security features and user friendliness of the bank website are play major role in customers satisfaction.

\subsection{Statement of Problems}

Rapid growth of information and communication technology in India changes the way of doing business, banking industry is not exception for that. Globalisation and liberalization has big impact in banks operational environment which leads to more automation in Indian banking industry. Globalisation pave the way for entering the more foreign banks in India which leads to edge over the competition among private and public sector banks in implementation of technological solutions. Foreign banks are early adopters of internet banking where as public sector banks are beginning to hold on to the competition. With this background the present study is an attempt to analysis the customer's satisfaction on internet banking services offered by foreign banks at Chennai city.

\subsection{Objectives of the study}

The following are the important objectives of the present study

- To identify the factors those are antecedents the customer's satisfaction in Internet Banking. 
- To measure the level of satisfactions of the customers using Internet banking.

\subsection{Hypothesis of the Study}

The following are important hypothesis of the present study.

- Customers using Internet banking services of foreign banks are satisfied with bank prompts responses.

- Customers using Internet banking services of foreign banks are satisfied with banking security.

- Customers using Internet banking services of foreign banks are satisfied with Reliability \& confidence.

- Customers using Internet banking services of foreign banks are satisfied with Efficiency of Website.

- Customers using Internet banking services of foreign banks are satisfied with Website Design.

\section{RESEARCH METHODOLOGY}

The important purpose carry out this study is to fulfill the significant gaps in customer satisfaction on internet banking services offered by foreign banks at Chennai city. The present is carried out during 2019. Data were collected from 200 customers availing internet banking services from foreign banks at Chennai city. Banks choosing for the present study is Standard Chartered Bank Ltd, Citibank, HSBC Bank, Deutsche Bank and DSB Bank. Data collected for the present study is unique is many aspects. First, the data covers only selected foreign banks at Chennai city offers internet banking services. Secondly, other relevant information required for the study was compiled from the websites of the respective banks.

\section{Limitations of the Study}

- The sample of the present study confined with only foreign banks operating in Chennai city.

- In the present only selected products and services of internet banking are studied. The internet banking products and services selected for the study are not final.

- The various products and services of internet banking offered by the foreign banks are obtained from their website only.

\section{ANALYSIS AND DISCUSSIONS}

To study the customers' satisfaction on internet banking services offered by foreign banks at Chennai city two important tests were employed. First one is KMO \& Bartlett's test to check whether the data is appropriate to proceed with the factor analysis or not. Second one is factor analysis to study six-dimension customer satisfaction variables.

Table 1 KMO \& Bartlett's Test

\begin{tabular}{|l|l|l|}
\hline \multicolumn{3}{|c|}{ KMO \& Bartlett's Test } \\
\hline \multicolumn{2}{|c|}{ KMO Measures of Sampling Adequacy } & 0.826 \\
\hline \multirow{3}{*}{ Bartlett's Test of Sphericity } & Approx. Chi-Square & 1642.14 \\
\cline { 2 - 3 } & Degree of Freedom & 264 \\
\cline { 2 - 3 } & Significance & 0 \\
\hline
\end{tabular}

The five-dimension customer satisfaction variables had Coefficient alpha of 0.826 . It is above the minimum standard score of 0.70 (Sekaran, 2005). KMO and Bartlett's test of 
Sphericity was significant (Chi-Square $-1642.14, \mathrm{p}<0.000$ ). (Kaiser, 1974) recommended that if KMO sample adequacy measure is above 0.60 it is good. In the present study The $\mathrm{KMO}$ measure of sampling adequacy was at 0.826 it is appropriate for factor analysis.

\subsection{A Frame Work of Factors Determining the Customers Satisfaction on Internet Banking}

This study provides antecedents of factors determining customer satisfaction in the Internet banking. The study found and categorized the repeated antecedents' factors into five categories: prompts responses, banking securities, Reliability \& Confidence, Efficiency of website and website design (Figure 1) categories.

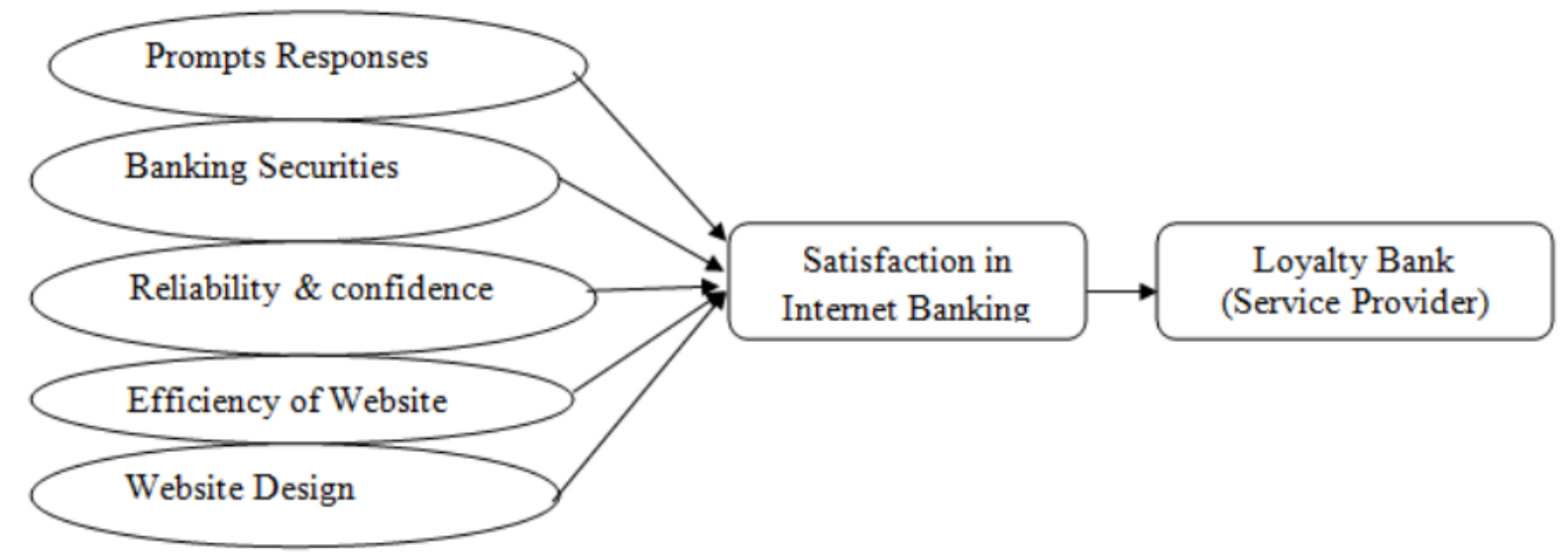

Figure 1

\subsection{Customer Satisfaction towards Internet Banking Services-Factor Analysis}

In the present study Principal Component Analysis method is employed to analyse the customer satisfaction on internet banking services offered by foreign banks. There are five variables used to analyse customer satisfactions they are internet banking-prompts responses, internet banking- securities, internet banking -reliability and confidence, internet banking efficiency of website, internet banking -website design.

Table 2 Internet banks -Prompts Responses

\begin{tabular}{|c|c|c|c|c|c|}
\hline S.No & $\begin{array}{l}\text { Variable } \\
\text { Consider }\end{array}$ & $\begin{array}{c}\text { Factor } \\
\text { loadings }\end{array}$ & Eigen values & $\begin{array}{l}\text { Percentage } \\
\text { of variance }\end{array}$ & Reliability \\
\hline 1 & speed \& accurate & 0.753 & \multirow{5}{*}{$\begin{array}{l}\text { (Cronbach } \alpha \\
=10.614)\end{array}$} & \multirow{5}{*}{15.426} & \multirow{5}{*}{$(0.852)$} \\
\hline 2 & Confirmation of transactions & 0.714 & & & \\
\hline 3 & Staff personal attention & 0.685 & & & \\
\hline 4 & Services delivered at exact time & 0.653 & & & \\
\hline 5 & Maintenance of error free records & 0.621 & & & \\
\hline
\end{tabular}

Table -2 shows the Internet banks - prompt responses. It is very clear from the table that variance is 15.426 under Principal Component Analysis for five factors with Eigen value exceeding 1.0. The variance up to 0.753 for speed \& accurate, 0.714 for confirmation of transactions, 0.685 for staff personal attention, 0.653 for Services delivered at exact and 0.621 for Maintenance of error free records by. Varimax rotation runs for five factors to find the factors determining the customer satisfaction. The factor analysis reveals that reliability measures exceeded the minimum value of 0.60 for all variables. Hence the hypothesis 1- 
Customers using Internet banking services of foreign banks are satisfied with bank prompts responses is accepted.

Table 3 Internet Banking- Security

\begin{tabular}{|c|c|c|c|c|c|}
\hline S.No & $\begin{array}{l}\text { Variable } \\
\text { Consider }\end{array}$ & $\begin{array}{c}\text { Factor } \\
\text { loadings }\end{array}$ & $\begin{array}{l}\text { Eigen } \\
\text { values }\end{array}$ & $\begin{array}{l}\text { Percentage } \\
\text { of variance }\end{array}$ & Reliability \\
\hline 1 & Security in Website & 0.942 & \multirow{4}{*}{$\begin{array}{l}\text { (Cronbach } \\
\alpha=6.438)\end{array}$} & \multirow{4}{*}{8.975} & \multirow{4}{*}{$(0.924)$} \\
\hline 2 & customer confidence & 0.874 & & & \\
\hline 3 & $\begin{array}{l}\text { Maintaining the confidential } \\
\text { information }\end{array}$ & 0.825 & & & \\
\hline 4 & $\begin{array}{l}\text { Updated the information in the } \\
\text { website }\end{array}$ & 0.763 & & & \\
\hline
\end{tabular}

Table -3 depicts Internet banking security. It is understand from the table that variance is 8.975 under Principal Component Analysis for four variables with Eigen value exceeding 1.0. The variance up to 0.942 for Security in Website, 0.874 for customer confidence, 0.835 for maintaining the confidential information and 0.763 for updated the information in the website. To find out customer satisfaction on internet banking security varimax rotation run for four variables and labeled accordingly. It is very clear from the analysis that reliability measure is above the minimum value of 0.60 under factor analysis. Hence the hypothesis- 2 Customers using Internet banking services of foreign banks are satisfied with banking security is accepted.

Table 4 Internet Banking- Reliability \& Confidence

\begin{tabular}{|c|c|c|c|c|c|}
\hline S.No & $\begin{array}{l}\text { Variable } \\
\text { Consider }\end{array}$ & $\begin{array}{c}\text { Factor } \\
\text { loadings }\end{array}$ & $\begin{array}{l}\text { Eigen } \\
\text { values }\end{array}$ & $\begin{array}{l}\text { Percentage } \\
\text { of variance }\end{array}$ & Reliability \\
\hline 1 & Keeping the promises & 0.931 & \multirow{3}{*}{$\begin{array}{l}\text { (Cronbach } \\
\alpha=4.216 \text { ) }\end{array}$} & \multirow{3}{*}{4.642} & \multirow{3}{*}{$(0.832)$} \\
\hline 2 & Access of financial information & 0.864 & & & \\
\hline 3 & Fulfill the needs of customers & 0.762 & & & \\
\hline
\end{tabular}

Table -4 depicts the Internet banking -Reliability \& Confidence. It is obvious from the study that variance is up 4.642 under Principal Component Analysis for three variables with Eigen value exceeding 1.0. The variance up to 0.931 for keeping the promises, 0.864 for access of financial information and 0.762 for fulfill the needs of customers. To find out customer satisfaction on internet banking reliability $\&$ confidence varimax rotation performed for three factors. The result of the analysis shows that reliability measure is above the minimum value of 0.60 for all variables. Hence the hypothesis -3 Customers using Internet banking services of foreign banks are satisfied with Reliability \& confidence are accepted.

Table 5 Internet Banking- Efficiency of Website

\begin{tabular}{|l|l|c|c|c|c|}
\hline S.No & \multicolumn{1}{|c|}{$\begin{array}{c}\text { Variable } \\
\text { Consider }\end{array}$} & $\begin{array}{c}\text { Factor } \\
\text { loadings }\end{array}$ & $\begin{array}{c}\text { Eigen } \\
\text { values }\end{array}$ & $\begin{array}{c}\text { Percentage } \\
\text { of variance }\end{array}$ & Reliability \\
\hline 1 & Website performance & 0.896 & $\begin{array}{c}(\text { Cronbach } \\
\alpha=1.647)\end{array}$ & 4.672 & \multirow{2}{*}{$(0.746)$} \\
\hline 2 & Keeping confidential information & 0.782 & & \\
\hline
\end{tabular}

Table -5 tells about the Internet banking-efficiency of website. It is understand from the study that variance is 4.672 under Principal Component Analysis for two variables with Eigen value exceeding 1.0. The variance up to 0.896 for website performance and 0.782 for keeping confidential information. To assess the efficiency of the website and customer satisfaction varimax rotation run for two variables. These variables were labeled accordingly. It is very 
clear from the analysis that reliability is above the minimum value of 0.60 under factor analysis for all variables. Hence the hypothesis -4 Customers using Internet banking services of foreign banks are satisfied with Efficiency of Website is accepted.

Table 6 Internet Banking- Website Design

\begin{tabular}{|c|c|c|c|c|c|}
\hline S.No & $\begin{array}{c}\text { Factors consider under internet } \\
\text { banking security }\end{array}$ & $\begin{array}{c}\text { Factor } \\
\text { loadings }\end{array}$ & $\begin{array}{l}\text { Eigen } \\
\text { values }\end{array}$ & $\begin{array}{l}\text { Percentage } \\
\text { of variance }\end{array}$ & Reliability \\
\hline 1 & Guidance in the screen & 0.796 & \multirow{4}{*}{$\begin{array}{l}\text { (Cronbach } \\
\alpha=2.465)\end{array}$} & \multirow{4}{*}{3.462} & \multirow{4}{*}{$(0.786)$} \\
\hline 2 & Services at right time & 0.764 & & & \\
\hline 3 & Quick delivery of services & 0.728 & & & \\
\hline 4 & Security system & 0.682 & & & \\
\hline
\end{tabular}

Table -7 provides Internet banking- website design. It is understands from the study that variance is 3.462 under Principal Component Analysis for four variables with Eigen value exceeding 1.0. This is very clear from the analysis that the variance up to 0.796 for guidance in the screen, 0.764 for services at right time, 0.728 for quick delivery of services and 0.682 for security system. The varimax rotation is run to determine customer satisfaction on Website Design for four variables. These variables were assigned accordingly. The result of the study shows that reliability exceeded the minimum value of 0.60 under factor analysis for all variables. Hence the hypothesis-5 Customers using Internet banking services of foreign banks are satisfied with Website Design is accepted.

\section{FINDINGS, SUGGESTIONS AND CONCLUSIONS}

\subsection{Findings from the Study}

This is very clear from the study that variables like internet banking security, internet banking-prompts responses, internet banking - reliability \& confidence, internet banking efficiency of website and internet banking - website design are influence the satisfactions of the customers of foreign banks who are using internet banking. This is obvious from the study that sample foreign banks are responding promptly for speed \& accurate, confirmation of transaction, staff personal attention, services delivered at time and maintained the error free records. Further sample foreign banks keep the security in website, customer confidence, maintaining the confidential information and updated the information in the website. Sample foreign banks full fill the promises for customers and fulfill the needs of the customers and maintained the bank website efficiently to perform the transactions as well as Keeping confidential information.

\subsection{Suggestions from the Study}

The sample foreign banks should circulate regular updates to customers regarding security, reliability and confidence, efficiency and web design using the latest technology. To performance the transaction more efficiently the sample foreign banks should maintained information and navigation steps in their web portal. The sample foreign banks should keep the adequate security measures for keep the customer's confidential information, services delivery and maintained the records. The sample foreign banks should customize their product and services to attract all categories of the customers. The sample banks to provide the facility to customer to complete their transactions at first attempt and complete their transactions very quickly through adopting the latest technology. 


\subsection{Conclusions}

The present study on customer satisfaction towards internet banking covers only selected foreign banks at Chennai City. It is very clear from the result of the study that sample foreign banks provide various modern features through internet banking using the latest technology to meet the needs of their customers. To attract more customers the sample foreign banks should offer the various add on services like insurance, mutual funds and other financial services apart from the crore banking services. The sample foreign banks should adopt the latest information and communication technology for render the services to their customers through that satisfy the needs of the customers. The study is limited to customer satisfaction on internet banking services provided by sample foreign banks. The sample foreign banks should conduct the periodic meetings to solve the customer's grievances. Further these sample banks conduct the regular survey to study changes in the customer's attitude, taste and preference in the internet banking.

\section{REFERENCES}

[1] Cronin, J. and Taylor, S. (1992), Measuring service quality: a re-examination and extension, Journal of Marketing, 56, pp.55-68.

[2] Gerrard, P. \& Cunningham, J.B. (2003), "The diffusion of Internet banking among Singapore consumers", Internet Journal of Bank Marketing, 21(1), pp.16-28.

[3] Awamleh, R., \& Fernandes, C. (2005) Internet banking: An empirical investigation into the extent of adoption by banks and the determinants of customer satisfaction in the UAE, Journal of Internet Banking and Commerce, 10(1), www. arraydev.com/commerce/jibc/200502/raedcedwyn1.HTM.

[4] Laforet, S \& Lo, X. (2005), "Consumers' attitudes towards online and mobile banking in China", International Journal of Bank Marketing, 23(5), P.p.362-380

[5] Raja.M and Dr.Clement Sudhahar.J.(2009) "Testing the Semi- Strong form Efficiency of Indian Stock Market with respect to Information Content of Stock Split Announcement - A Study in IT Industry", International Research Journal of Finance and Economics, Vol. 20, No.1, March -2009, P.p 07-20

[6] Baskar, S. \& Ramesh.M (2010), Linkage between online banking service quality and customers, Perspectives of Innovations, Economics \& Business, 6(3), pp.45-51.

[7] Konstantinos Terzidis, Eva Papadopoulos and Kosmas Kosmidis (2013) "Customer e-loyalty to internet banking -An empirical analysis", Global Business Economic Review, Vol.15, No.2, P.p-148-162.

[8] Dr.M.Raja, Dr.R.Venkatamuni Reddy And Dr.M.Muthugopalakrishnan (2018), "A study on optimal portfolio construction with special reference to CNX Nifty Pharma Index" International Journal of Civil Engineering and Technology (IJCIET), Volume 9, Issue 13, December 2018, pp.1355-1363.

[9] Vigneshwari and S.Rajagopalan (2018), "Customer satisfaction toward online banking services", International Journal of Pure and Applied Mathematics, Volume 119, No. 18, P.p2909-2916

[10] Dr.Kiran.G, Dr.Appasaba.L.V, Dr.M.Raja, Dr M. Muthu Gopalakrishnan, Dr. Nila Chotai (2020), "Customer satisfaction towards online banking services of public sector banks", International Journal of Scientific \& Technology Research, Vol.9, Issue-4, P.p - 3368-3372. 